\title{
A Review of the Potential Issues of Pollution Caused by the Mineral Elements, Mercury, Lead and Arsenic, Its Possible Impacts on the Human Beings and the Suggested Solutions
}

\author{
Yau Lam ${ }^{1}$, Cho Wing Sze', Yao Tong ${ }^{1}$, Tzi Bun Ng${ }^{2}$, Pang Chui Shaw ${ }^{3}$, Yanbo Zhang ${ }^{1}$ \\ ${ }^{1}$ School of Chinese Medicine, The University of Hong Kong, Hong Kong, China \\ ${ }^{2}$ The School of Biomedical Sciences and School of Life Science, The University of Hong Kong, Hong Kong, China \\ ${ }^{3}$ The School of Biochemistry and Faculty of Science, The Chinese University of Hong Kong, Hong Kong, China \\ Email: ybzhang@hkucc.hku.hk
}

Received August 23, 2012; revised October 16, 2012; accepted November 2, 2012

\begin{abstract}
Objective: This paper mainly discusses and summarises the potential issues of pollution caused by the Mineral elements, Mercury, Lead and Arsenic, its possible impacts on the human beings and the suggested solutions. Methods: This paper is prepared by reviewing the latest academic literatures. Result: First, this article discusses two aspects including the effects of Mercury, Lead and Arsenic on the Chinese herbal medicine and the potential issues of causing the environmental pollution. And then further study its toxicity effects and the side impacts on the human bodies in order to realize the actual circumstances people are encountering nowadays. This paper will also the corresponding its treatment method of reviews. Hope this will provide a valuable reference. Conclusion: Theses issues caused by the Mineral elements are prominent nowadays, thus the ongoing researches on the impacts of pollution and the possible solutions are regarded as highly valued in order to conserve the natural environment and meanwhile safeguard the well beings of people and the future offspring.
\end{abstract}

Keywords: Mineral Elements; Arsenic; Lead; Mercury

\section{Introduction}

With the continuous development of the science, more and more serious pollutions stem from Mineral elements, including arsenic, lead, mercury, cadmium, nickel, copper and zinc, fierce, and sources etc. The sources of pollutions are very broad, factors including environment, food and drugs. This paper mainly discusses three Mineral elements, Mercury, Lead and Arsenic. The focuses are mainly on the basis of environment and drugs. We can also realize the extent of harm of the heavy metals on the human health and the feasible methods in resolving the health impacts.

\section{Pollution of Mercury, Lead and Arsenic}

Rapid economic development in countries and concern for both the environment and protection against pollutants is increasing. Identification of sources of contaminants and evaluation of current environmental status are essential to environmental pollution management. Mining and metallurgical activities these anthropogenic Mineral elements from the contaminated areas into the envi- ronment. Harmful Mineral elements included Mercury, Lead and Arsenic. Lead is used in many industries, including lead smelting and processing, the manufacturing of batteries, pigments, solder, plastics, cable sheathing, ammunition, ceramics, and battery recycling. It was the most common Mineral elements contaminant [1-3]. Arsenic contamination in the arises due to human activities like mining, combustion, and pesticide application. As indicated by the presence of pyrite, hydrous ferric oxide, organic matter, clay minerals, fracture surfaces, and high permeable (moldic) zones. Arsenic was present in all of the stratigraphic units at low concentrations, close to the global average for as in limestone of $2.6 \mathrm{mg} / \mathrm{kg}$. The highest As concentration was $69 \mathrm{mg} / \mathrm{kg}[4,5]$. Mercury was common Mineral elements in home contamination. If you broken thermostats or from the accidental or intentional spilling or sprinkling of elemental mercury. Because it can easily trapped in porous surfaces such as plaster or stucco interiors, carpeting or cracks between tile or wood floors. So it may persist in an indoor environment for several years. There are many publications in the scientific literature addressing this issue, including 
several excellent reviews. This type of contamination is a public health issue worldwide. In particular the ongoing catastrophic problems in Bangladesh and West Bengal have been front-page stories in newspapers and scientific journals [6-9].

Toxic contaminant release; toxic substances can follow different environmental pathways and accumulate in environmental soil and elevated concentrations of toxic metals. Metals are persistent in soils for a longer time after their introduction, and most metals do not undergo microbial or chemical degradation. Such as deforestation and soil erosion, inevitably resulted in environmental degradation in the surrounding seas induced historical soil and groundwater pollution by Mineral elements. That is a worldwide problem (Tables 1 and 2).

\section{Traditional Chinese Medicine and Proprietary Chinese Medicines in Mineral Elements of Arsenic, Mercury and Lead}

In recent years, the total number of people using traditional Chinese herbal medicine is vast and steadily increasing in East Asian countries and Chinese society. The industrial output value of traditional Chinese herbal medicine has also continued to expand rapidly across the world since the year 2000 [43]. Thereafter, the united states studies show, that approximately 14.8 billion USD were spent in 2007 on non-mineral, non-vitamin natural products, most of which consisted of herbal medicines,

Table 1. Comparisons of the concentrations of trace metals in urban soils of different cities in China $\left(\mathrm{mg}^{\circ} \mathrm{kg}^{-1}\right)$.

\begin{tabular}{|c|c|c|c|c|}
\hline \multicolumn{5}{|c|}{ Soils pollution } \\
\hline $\begin{array}{l}\text { Chinese } \\
\text { provinces } \\
\text { and cities }\end{array}$ & $\mathrm{Pb}$ & $\mathrm{Hg}$ & As & Reference \\
\hline Beijing & $25.5-208$ & n.d & n.d & {$[10]$} \\
\hline Changchun & $19.7-378$ & $0.026-1.43$ & $6.1-67.7$ & {$[11,12]$} \\
\hline (Jilin) & 28.8 & 0.037 & 8.0 & [13] \\
\hline Changsha & $7.80-413$ & $0.050-1.29$ & $2.49-79.8$ & [13] \\
\hline (Hunan) & 29.7 & 0.12 & 15.7 & [13] \\
\hline Chongqing & $13.5-53.9$ & $0.049-0.89$ & $4.12-18.9$ & {$[14]$} \\
\hline (Sichuan) & 30.9 & 0.061 & 10.4 & [14] \\
\hline Fuzhou & $22.8-1072$ & $0.020-6.24$ & $1.39-42.2$ & [15] \\
\hline (Fujian) & 41.3 & 0.093 & 6.30 & {$[15]$} \\
\hline $\begin{array}{l}\text { The chart abov } \\
n \text { the soil of } \\
\text { distribution of } \\
\text { cities; convers } \\
\text { han that of pr } \\
\text { cury in the soil }\end{array}$ & $\begin{array}{l}\text { ndicates the } \\
\text { provinces } \\
\text { ad element } \\
\text { the distrib } \\
\text { nces; the di } \\
\text { both provin }\end{array}$ & $\begin{array}{l}\text { ribution statu } \\
\text { cities of } \mathrm{Ch} \\
\text { he soil of pr } \\
\text { n of arsenic } \\
\text { pancy is muc } \\
\text { and cities. }\end{array}$ & $\begin{array}{l}\text { f lead, merct } \\
\text { The results } \\
\text { nces is high } \\
\text { the soil of } \\
\text { ess for the c }\end{array}$ & $\begin{array}{l}\text { ry and arsenic } \\
\text { show that the } \\
r \text { than that of } \\
\text { ties is higher } \\
\text { ntent of mer- }\end{array}$ \\
\hline
\end{tabular}

Table 2. Concentration of several elements $\left(\mathrm{mg} \cdot \mathrm{kg}^{-1}\right)$ found in sediments collected in different estuaries of the world.

\begin{tabular}{|c|c|c|c|}
\hline \multicolumn{4}{|c|}{ Pollution of Estuary } \\
\hline Around the world in Estuary & $\mathrm{Pb}$ & As & Reference \\
\hline 1. Medway (UK) & 67 & 14 & [16] \\
\hline 2. Thames (UK) & 63 & 15 & [17] \\
\hline 3. Odiel-Tinto (Spain) & 523 & 278 & {$[18]$} \\
\hline 4. Nerbioi-Ibaizabal & $21-445$ & $0.6-220$ & [19] \\
\hline 5. Krka (Croatia) & 11 & n.d & {$[20]$} \\
\hline 6. St Lucie (Florida) & $2.8-23$ & n.d & [21] \\
\hline 7. Vigo (Spain) & 57 & n.d & {$[22]$} \\
\hline 8. Mersey (UK) & 65 & n.d & [23] \\
\hline 9. Hudson (New York) & 81 & n.d & [24] \\
\hline 10. Pearl River (China) & $16-93.3$ & n.d & {$[25]$} \\
\hline 11. Severn (UK) & $50-68$ & n.d & [26] \\
\hline 12. Tagus (Portugal) & $65-200$ & n.d & [27] \\
\hline 13. Ulla (Spain) & $57-58$ & n.d & {$[28]$} \\
\hline 14. Marabasco (Mexico) & $2-18$ & n.d & [29] \\
\hline 15. Pontevedra (Spain) & $37-144$ & n.d & {$[30]$} \\
\hline 16. Ennore Creek (India) & 32 & n.d & [31] \\
\hline 17. Tamaki (New Zeeland) & $51-122$ & n.d & {$[32]$} \\
\hline 18. Pearl River Estuary (China) & 59.4 & n.d & [33] \\
\hline 19. Shenzhen Bay (China) & 46.0 & n.d & [34] \\
\hline 20. Jiaozhou Bay (China) & 30.9 & n.d & {$[35]$} \\
\hline 21. Quanzhou Bay (China) & $34.3 \pm 16.9$ & n.d & {$[36]$} \\
\hline 22. Western Xiamen Bay (China) & 50.0 & n.d & [37] \\
\hline 23. New York Harbor (USA) & $109-136$ & n.d & [38] \\
\hline 24. Bremen Harbor (Germany) & 122 & n.d & [39] \\
\hline 25. Izmir Harbor (Turkey) & 97 & n.d & \\
\hline 26. Boston Harbor (USA) & 86 & n.d & [40] \\
\hline $\begin{array}{l}\text { 27. Marine Sediment Quality } \\
\text { Primary standard criteria }\end{array}$ & 60 & n.d & {$[41]$} \\
\hline $\begin{array}{l}\text { 28. Marine Sediment Quality } \\
\text { Secondary standard criteria }\end{array}$ & 130 & n.d & {$[41]$} \\
\hline $\begin{array}{l}\text { 29. Sediment guideline for } \\
\text { effects range-low (ERL) }\end{array}$ & 46.7 & n.d & {$[42]$} \\
\hline 30. South China Sea (China) & $23.6 \pm 8.9$ & n.d & [42] \\
\hline
\end{tabular}

The above chart indicates the extent of air pollution triggered by lead and arsenic in different countries. The results show that the extent of air pollution triggered by the elements in the countries such as United States, China and India are different. There is less data obtained for the analysis of arsenic element. Based on all available information, the extent of pollution triggered by lead is higher than that of arsenic. 
up from an estimated total of 6.6 billion USD spent ten years previously but several studies have shown that CHMs and other botanical supplements may be contaminated with minerals and metals 15 , also in some cases at toxic levels. Much of what has been reported regarding potentially worrisome contamination in herbal medicines relates to patent or proprietary medicines [4446].

We learned that Proprietary Chinese Medicines can produce Mineral elements poisoning and that physicians need to take patient histories carefully, being aware of the possible side effects of herbal medicines. In traditional Chinese medicine, mercury and arsenic is part of some preparations. In which "calomel" (mercury chloride) or "hydrargyri oxydum rubrum" (mercury oxide) and it contains $10 \%$ cinnabar $\mathrm{HgS}$ (mercury sulfide) of AnGong-Niu-Huang Wan (AGNH) [47]. Also that arsenic including arsenolite, orpiment (mainly containing $\mathrm{As}_{2} \mathrm{~S}_{3}$ ), realgar (mainly containing $\mathrm{As}_{4} \mathrm{~S}_{4}$ ), arsenolite and arsenic trioxide (mainly containing $\mathrm{As}_{2} \mathrm{O}_{3}$ ) [48]. It has long been used in traditional medicine for treating various diseases but in some cases at toxic levels [49].

\subsection{Orpiment, Realgar and Arsenic Stone Toxicity of Mineral Elements}

Arsenical preparations have been used by many physiccians in the treatment of malignant diseases, such as leukemia, Hodgkin's disease, pernicious anemia and nonmalignant diseases, such as psoriasis, pemphigus, eczema, and asthma for centuries [50]. Recent studies prove that realgar is used to counteract toxicity, kill parasites, and cure malaria [51]. Also that orpiment nanoparticles can inhibit the telomerase activity of K562 cells, which may be an important mechanism in the anticancer effect of orpiment nanoparticles [52,53]. In fact, it is a known human carcinogen producing a series of organic cancers and has many other profound toxic effects following short-term or long-term exposure [54]. In which, arsenolite and arsenic trioxide are highly toxic compared to orpiment and realgar. Short-term toxicity of $\mathrm{As}_{2} \mathrm{O}_{3}$ is the major concern in the use of this agent against malignancies, and at least three sudden deaths have been reported [55]. To ensure the safe use of mineral arsenicals, identifying them accurately is necessary (Table $\mathbf{3}$ ).

\subsection{An-Gong-Niu-Huang Wan (AGNH) Toxicity of Mineral Elements (Mercury)}

An-Gong-Niu-Huang Wan (AGNH) is a patent traditional Chinese medicine for brain disorders. The medicine containing cinnabar is insoluble, has very low bioavailability and thus is poorly absorbed from the gastrointestinal tract. In study display, long-term administration (>30 days) of cinnabar at doses above $100 \mathrm{mg} / \mathrm{kg}$ also produced mercury poisoning [56]. In addition, heating cinnabar results in release of mercury vapor, which in turn can produce toxicity similar to inhalation of these vapors [57]. The cinnabar which contains 96\% mercuric sulfide (HgS), Mercury binds to other elements, such as chlorine, sulfur, or oxygen, to form inorganic mercurous $\left(\mathrm{Hg}_{1} \mathrm{p}\right)$ or mercuric $\left(\mathrm{Hg}_{2} \mathrm{p}\right)$ salts, such as mercury sulfide (HgS, purified from cinnabar), mercurous chloride $\left(\mathrm{Hg}_{2} \mathrm{Cl}_{2}\right.$, also called calomel) and mercuric chloride $\left(\mathrm{HgCl}_{2}\right)$ [58]. In which ethyl mercury $\left(\mathrm{C}_{2} \mathrm{H}_{5} \mathrm{Hgp}\right)$ is the major component of thimerosal. Mercuric oxide was once used as a disinfectant and antiseptic agent [59]. Other preparations containing mercury are still used as antibacterials [60] but dimethyl mercury $\left[\left(\mathrm{CH}_{3}\right) 2 \mathrm{Hg}\right]$ is the most toxic mercurial [61]. The abuse of cinnabar leading to intoxication of $\mathrm{Hg}$ in infants has been reported so these uses have largely been replaced by safer therapies $[62,63]$ (Table 4).

\subsection{Mineral Elements of Hongdan $\left(\mathrm{Pb}_{3} \mathrm{O}_{4}\right)$ and Lead}

Hongdan is the official term for red lead $\left(\mathrm{Pb}_{3} \mathrm{O}_{4}\right)$ according to the pharmacopeia of traditional Chinese medicine. In addition to its use in traditional medicine, Hongdan is widely used in paint and in the battery industry as a raw or additive material. Also, used for superstitious purposes (by low income families in China) as a cultural

Table 3. Effect of metallic element to human health (Hg), (As) and (Pb) $[65,66]$.

\begin{tabular}{ccc}
\hline Diseases & $\begin{array}{c}\text { Toxic metals potentially } \\
\text { involved in etiology }\end{array}$ & Reference \\
\hline Allergy & $\mathrm{Hg}$ & {$[67,68]$} \\
Autism & $\mathrm{Hg}$ & {$[69]$} \\
$\begin{array}{c}\text { Parkinson's } \\
\text { disease } \\
\begin{array}{c}\text { Poisoning and } \\
\text { anemia }\end{array}\end{array}$ & $\mathrm{Hg}, \mathrm{Pb}, \mathrm{As}$ & {$[70,71]$} \\
Diabetes & $\mathrm{Pb}$ & {$[72]$} \\
\hline
\end{tabular}

The above chart indicates that the lead, mercury and arsenic poisoning could cause certain diseases among which Parkinson's disease is the common disease which could be caused by all three of the elements.

Table 4. Hg (10 mg/kg) for 10 weeks on liver, kidney, cerebral and cerebellar injury of male and female [72].

\begin{tabular}{ccccc}
\hline & Cerebral & Cerebellar & Liver & Kidney \\
\hline & Cortex & Cortex & & \\
\cline { 2 - 5 } Male & $15 \mu \mathrm{g} / \mathrm{g}$ & $21 \mu \mathrm{g} / \mathrm{g}$ & $112 \mu \mathrm{g} / \mathrm{g}$ & $180 \mu \mathrm{g} / \mathrm{g}$ \\
Female & $9 \mu \mathrm{g} / \mathrm{g}$ & $18 \mu \mathrm{g} / \mathrm{g}$ & $80 \mu \mathrm{g} / \mathrm{g}$ & $140 \mu \mathrm{g} / \mathrm{g}$ \\
\hline
\end{tabular}

The above chart indicates that mercury could cause damages of Cerebral cortex, cerebellar cortex, liver and kidney for both males and females. Overall, the damages to males are more serious than that to females. 
powder to ward off bad luck by daubing. Use to traditional medicine, Though most qualified physicians are aware of its potential toxicity, most traditional medicine practitioners are not certificated to practice. In April 2009, the national Food and Drug Administration responded to the report and launched a campaign nationwide. Until now, China as a suggestion to prohibit the use of Hongdan as a remedy [64].

\section{Lead, Mercury and Arsenic Poisoning and Its Treatment Method}

Lead $(\mathrm{Pb})$, mercury $(\mathrm{Hg})$ and arsenic (As) are metals ranked among the top ten most toxic substances, summarized as follows [73].

\subsection{The Toxicity of Lead}

We defined high lead content to be $>1.5 \mathrm{mcg} / \mathrm{serving}$. The early European Pharmacopoeia has issued a draft monograph herbal drugs, proposing the limits for Mineral elements in herbal drugs: $5 \mathrm{mg} \cdot \mathrm{kg}^{-1}$ for lead, furthermore, the European Commission has established the lead limits in food supplements of America [74,75].

After that, in America, California criteria for acceptable lead levels of $<1.5 \mathrm{mcg} / \mathrm{serving}$ of natural calcium supplement.

Lead is mainly divided into two kinds of structure: Inorganic and organic. Inorganic and organic forms of lead are absorbed through the lungs and gastrointestinal tract; in occupational settings, exposure through inhalation is more common, whereas in the general population, it is largely through ingestion. And organic lead compounds may also be absorbed through the skin [76]. Excretion is primarily via the kidneys, and the half-life of lead in the blood is about 30 days. If high lead is taken up in the blood and deposited in soft tissues (brain, liver, kidney, bone marrow) and bone up to $94 \%$ of the body burden of lead is in bone, where it has a half-life of years to decades [77]. A clinical report showed, ordinary people may include abdominal pain, anorexia, nausea and constipation, headache, joint and muscle pain, difficulties with concentration and memory, sleep disturbances, anemia with basophilic stippling, peripheral neuropathy and nephropathy [78]. Among adults, the potential implications of low-level lead exposure are most relevant to women of child-bearing age, as lead is especially harmful to developing nervous systems of fetuses and children and passes through the placenta and breast milk [79-81]. As lead accumulates in bones and is mobilized into circulation during periods of increased bone turnover (particularly in women during periods of pregnancy, lactation, and menopause). Calcium deficiency increases lead absorption and lead retention, and is a risk factor for increased maternal lead transfer. In which, Methyl mercury crosses the placenta and reaches the fetus, and is concentrated in the fetal brain at least 5 to 7 times that of maternal blood [82-86]. Prenatal methyl mercury exposure at high levels can induce widespread damage to the fetal brain. Given birth to infants with severe developmental disabilities, raising initial concerns for mercury as a developmental toxicant. The child's brain and nervous system equally susceptible to its effect of lead [87].

\subsection{The Toxicity of Mercury}

Mercury is known to produce toxicity of Mineral elements. The European Pharmacopoeia has issued a draft monograph Herbal drugs, proposing the following limits for heavy metals in herbal drugs: $0.1 \mathrm{mg} \cdot \mathrm{kg}^{-1}$ for mercury. Furthermore, the European Commission has established the mercury limits in food supplements [88]. Mercury is mainly divided into two kinds of structure: Inorganic and organic. It is distributed primarily to the central nervous system and the kidneys. Elimination is through the urine and feces. The half-life of elemental and inorganic mercury in the blood is 40 - 60 days, and the half-life of organic mercury in the blood is about 70 days. Signs and symptoms of mercury toxicity vary with the form of mercury and route of exposure [89]. In which, inhalation of high concentrations of elemental mercury vapor also damages the lungs, skin, eyes, and gingival. Chronic exposure to elemental mercury vapor primarily affects the central nervous system. Major symptoms include a fine tremor, psychological changes (e.g., increased excitability), and gingivitis. Other symptoms can include insomnia, loss of appetite, irritability, depression, headache, short-term memory loss, and muscle wasting [90]. Symptoms of acute exposure include cough, dyspnea, chest pain, nausea, vomiting, diarrhea, fever, and a metallic taste in the mouth. If the exposure is great enough, these symptoms can progress to interstitial pneumonitis, renal injury, increased blood pressure and heart rate, and pulmonary edema [91]. In which, the woman developed a variety of symptoms, including pain and tingling in one hand, abdominal pain and bloating, diarrhea and constipation, increased bruising, varicose veins and fatigue. In the fetus, organic mercury disrupts the cytoarchitecture of the developing brain and has been associated with neuropsychological changes after birth [92].

\subsection{The Toxicity of Arsenic}

Arsenic is a poison since ancient times. It is a geogenic water menace affecting millions of people all over the world and is regarded as the largest mass poisoning in history. Moreover, it has been used as a Chinese herbal medicine and proprietary Chinese medicines for many centuries [93]. In force since 1 July 2009, shows national 
and regional limits for arsenic and toxic metals in various types of herbal products proposed by the WHO [94]. Therefore, removal and recovery of arsenic from contaminated water and effective and safe use of mineral arsenicals has attracted more and more attention. Arsenic occurs in the environment in several chemical forms, showing different toxicological characteristics. Organic forms of arsenic are rarely significant in ground water, however, the inorganic forms: arsenite $\left(\mathrm{AsO}_{3}^{3-}\right)$ and arsenate $\left(\mathrm{AsO}_{3}^{3-}\right)$ are often found in this kind of water. Permanent arsenic intake leads to chronic intoxication. Dosages much lower than this have been associated with a variety of adverse health effects including mild symptoms such as throat irritation, nausea, and more serious signs of intoxication such as anaemia, liver injury, skin injury, renal failure, encephalopathy and a gastrointestinal bleeding [95]. Prenatal exposure to arsenic is associated with later life health effects in adults [96-98]. Toxic metal exposures in utero and during childhood may result in significant health effects including, low birth weight, reduced fetal growth and reproductive and cognitive deficits in adolescents [99-101]. Results in the appearance of diverse types of cancer, such as hyperkeratosis, lung, and skin cancer.Increased mortality and increased risk $[102,103]$. Once the report display, the Vietnamese pills have caused a classic case of fatal arsenic poisoning in Vietnam [104].

\section{Determination of Lead, Mercury and Arsenic}

\subsection{Determination of Lead}

The lead pollution comes mainly from environmental factors. Asia and America same affected by pollution [105]. In China, the powder was analyzed in a chemistry laboratory in Guangzhou Center for Disease Control. There use to flame atomic absorption spectrometry (FAAS, Zeeman-5000, Hitachi Limited, Japan) and use to situ XRF for structure determination of lead. In addition, China specializing in lead poisoning treatment. The BLLs were measured again by graphite furnace atomic absorption spectrometry with Zeeman back-ground correction (GFAAS; Thermo Elemental, Solaar MQZ) in the hospital [106]. The lead structure included: $\mathrm{Pb}\left(\mathrm{NO}_{3}\right)_{2}$; $\mathrm{Pb}\left(\mathrm{C}_{2} \mathrm{H}_{5}\right)_{4} ; \mathrm{PbCO}_{3} ; \mathrm{PbSiO}_{3} ; \mathrm{PbCrO}_{4} ; \mathrm{PbO}_{2} ; \mathrm{PbO}$ (litharge); $\mathrm{PbO}$ (massicot) et al. [107]. Based on the sample analysis using inductively coupled plasma mass spectrometry (ICP-MS) [108].

In USA of El Paso and TX have been used synchrotron-based XAFS (X-ray absorption fine structure) to identify and quantify the major $\mathrm{Pb}$ species present in airborne PM collected so. It can bulk technique that provides structural information at the molecular level about a given element in a sample and hence used to environ- mental testing. If you visited the family to investigate the source of lead exposure used to a portable X-ray fluorescence analyzer (XRF, Innov- $\alpha$ 4000, Innov-X System Company, Woburn, MA) was used to screen the indoor environment, household products, drinking water and food [109]. Hence, in lead poisoning treatment use of (GFAAS); in the pharmaceutical analysis and the environmental pollution can be used on X-ray fluorescence spectrometry [110].

\subsection{Determination of Mercury}

Several techniques are currently available in the determination of mercury and these include cold vapor atomic absorption/fluorescence spectrometry (CV-AAS/AFS), gas and liquid chromatography (GC/LC) and inductively coupled plasma with either atomic emission spectrometry (ICP-AES) or mass spectrometry (ICP-MS), etc. [111, 112]. Laboratory studies revealed, urine specimens were analyzed for inorganic mercury using an automated flow injection mercury system (FIMS) that uses cold vapor atomic absorption spectrometry and Urine specimens were analyzed for total mercury using inductively coupled plasma mass spectrometry (ICP-MS) [113-115]. CVG technique has some merits such as high sensitivity, wide linear dynamic range, low noise level, fast analysis speed, ease of operation, and low cost [116]. However, the drawbacks are also serious and remarkable. This sample pre-treatment step is time-consuming. moreover potential losses of the volatile mercury species in the sample may also occur and quite often also the major source of contamination, Furthermore, still some difficulties exist in the analysis of mercury in some TCM drugs because of its extremely low concentrations following the interferences caused by the complex sample matrices and the wide change in matrix composition from sample to sample [117]. Comparing with other technique, the thermolysis atomic absorption method provides an attractive alternative in mercury analysis, because of its direct solid sampling without pre-treatment, which eliminates tedious sample digestion or derivatization steps commonly used in conventional methods. The method is rapid, typically requiring only $4 \mathrm{~min}$ to complete a total mercury analysis. Moreover, the method provides high sensitivity, low detection limit and outstanding background correction capability utilizing Zeeman-effect. In this study, our objective is to develop and apply this technique to investigate the content of mercury and the preliminary species in several TCM drug products for quality assessment and regulatory purposes [118,119].

\subsection{Determination of Arsenic}

Determination of arsenic in many methods including: 
X-ray diffraction analysis [120]; Hydride generation (HG), liquid chromatography (LC), gas chromatography (GC) and capillary electrophoresis (CE) are commonly being utilized for the separation of as species. However, the advantage of HG method is that it can easily be connected to various detection systems like ICP-MS, AAS, ETAAS, ICPAES, AFS, and ICP-MS [121-123]. The most commonly analyzed species are $\mathrm{As}(\mathrm{III}), \mathrm{As}(\mathrm{V})$, MMAA, DMAA, arsenocholine (AsC), arsenobetaine (AsB) or $\mathrm{TMAs}^{+}$(tetramethylarsonium ion- $\mathrm{Me}_{4} \mathrm{As}^{+}$), TMAO (trimethylarsine oxide- $\mathrm{Me}_{3} \mathrm{AsO}$ ), arsenosugars, phenylarsonic acid (PAS) and metaloproteins [124].

The commonly used to Hydride generation of HGAAS method, because of Hydride generation is a wellknown technique for the determination of As at trace levels, which consists of the reaction of As compounds with sodium tetrahydroborate in acidic medium to produce various arsines (AsH3) [125]. As for example, $\mathrm{As}(\mathrm{III})$ and $\mathrm{As}(\mathrm{V})$ give AsH3, MMAA gives monomethylarsine (MMA-CH3AsH2) and DMAA produces dimethylarsine (DMA-(CH3)2AsH). Also, the AAS combined with HG is widely used for As speciation included, $\mathrm{As}(\mathrm{III})$ and $\mathrm{As}(\mathrm{V})[126,127]$. It has been specific advantages included, selectivity, sensitivity, efficiency, rapidity and detection limit (DL), in addition, often combined with high performance liquid chromatography. The use of HPLC-HG-AAS enabled the elimination of interfereence and the highly sensitive determination of $\mathrm{As}(\mathrm{V})$ [128].

After that, the macroscopic and microscopic features are given in detail. In study display, that modern microscopic technique is a simple, fast, effective, low cost, and the results are in agreement with ICP-MS analysis. The authentication results for arsenolite and arsenic trioxide same are confirmed by ICP-MS analysis. But there are a lot of problems included inductively coupled plasma atomic emission spectrometry (ICPAES) [129], inductively coupled plasma mass spectrometry (ICP-MS) [130-134], graphite furnace atomic absorption spectrometry (GFAAS) [135], hydride generation atomic absorption spectrometry (HGAAS) [136], and hydride generation atomic fluorescence spectrometry (HG-AFS) [137]. These methodologies are often laboratory-based and timeconsuming and may lead to large capital cost for multisample analysis and its major drawback is that these methods are unable to distinguish between As(III) and $\mathrm{As}(\mathrm{V})$ in the analyzed samples.

Recent studies, a novel hyphenated technique, a microfluidic chip-based capillary electrophoresis ( $\mu$ chip-CE) hydride generation $(\mathrm{HG})$ system was interfaced with a microwave induced plasma optical emission spectrometry (MIP-OES) to provide two inorganic arsenic species separation capabilities. The detection limits for As(III) and $\mathrm{As}(\mathrm{V})$ are 3.9 and $5.4 \mathrm{ng} \cdot \mathrm{mL}^{-1}$, at the moment the microchip system requires manual filling with background buffer and sample. Further improvements of the features of $\mu$ CE-HG-MIP-OES may lie in the use of aminiaturized MIP at atmospheric pressure and miniaturized and portable spectrometer because toxic of hevy metal $\mathrm{As}(\mathrm{V})$ is much higher than that of $\mathrm{As}(\mathrm{III})[138,139]$. There are few proposed methods to the direct determination of $\operatorname{As}(\mathrm{V})$, without pretreatment of samples. Today, a colorimetric method using the molybdenum blue complex has been developed for the sensitive de- termination of $\mathrm{As}(\mathrm{V})[140]$.

\section{Conclusion}

Based on the research conducted in this article, it is apparent that the pollutions of heavy metal stem from a variety of cause. It could devastate the health of wildlife and human beings, especially to the pregnant females and the fetus. The impact on the mental growth could prolong from the new born to the childhood and result in an irreparable jeopardy. As a matter of fact, many might have acknowledged that heavy metal pollutions are inevitable by-products during the exploration and development of society, therefore, in-depth study of the methods in resolving the heavy metal pollution is an important subject. In the future, in addition to enhance heavy metal to detection, also should consider the mineral traditional Chinese medicine on dosage and use method and the related problems, ensure the safety of medication.

\section{Acknowledgements}

This study was supported by Funding from Innovation and Technology Support Programme, the Government of the Hong Kong Special Administrative Region No. ITS/ 313/11 and Seed Funding Programme for Basic Research from The Hong Kong University No. 201111159043.

\section{REFERENCES}

[1] Y. W. Chiang, R. M. Santos, K. Ghyselbrecht, V. Cappuyns, J. A. Martens, R. Swennen, T. Van Gerven and B. Meesschaert, "Strategic Selection of an Optimal Sorbent Mixture for in-Situ Remediation of Heavy Metal Contaminated Sediments: Framework and Case Study," Journal of Environmental Management, Vol. 105, 2012, pp. 111.

[2] A. Fischbein, "Occupational and Environmental Exposure to Lead," In: W. N. Rom, Ed., Environmental and Occupational Medicine, 3rd Edition, Lippincott-Raven, Philadelphia, 1998, pp. 973-996.

[3] T. S. Bowers, B. D. Beck and H. S. Karam, "Assessing the Relationship between Environmental Lead Concentrations and Adult Blood Lead Levels," Risk Analysis, Vol. 14, No. 2, 1994, pp. 183-189.

[4] A. A. Carbonell-Barrachina, M. A. Aarabi, R. D. Delaune, R. P. Gambrell and J. W. H. Patrick, "Arsenic in Wetland 
Vegetation: Availability, Phytotoxicity, Uptake and Effects on Plant Growth and Nutrition," Science of the Total Environment, Vol. 217, No. 3, 1998, pp. 189-199.

[5] T. Pichler, R. Price, O. Lazareva and A. Dippold, "Determination of Arsenic Concentration and Distribution in the Floridan Aquifer System," Journal of Geochemical Exploration, Vol. 111, No. 3, 2011, pp. 84-96.

[6] L. H. Zayas and P. O. Ozuah, "Mercury Use in Espiritismo: A Survey of Botanicas," American Journal of Public Health, Vol. 86, No. 1, 1996, pp. 111-112. doi:10.2105/AJPH.86.1.111

[7] Association of Toxic Substances and Disease Registry (ATSDR), "Toxicological Profile for Mercury (Update)," Department of Health and Human Services, Atlanta, 2006. http://www.atsdr.cdc.gov/toxprofiles/tp46.html

[8] M. Amini, K. C. Abbaspour, M. Berg, L. Winkel, S. J. Hug, E. Hoehn, H. Yang and C. A. Johnson, "Statistical Modeling of Global Geogenic Arsenic Contamination in Groundwater," Environmental Science \& Technology, Vol. 42, No. 10, 2008, pp. 3669-3675.

[9] M. F. Ahmed, S. Ahuja, M. Alauddin, S. J. Hug, J. R. Lloyd, A. Pfaff, T. Pichler, C. Saltikov, M. Stute and A. van Geen, "Ensuring Safe Drinking Water in Bangladesh. Science," 2006. doi:10.1126/science. 1133146

[10] T. B. Chen, Y. M. Zheng, M. Lei, Z. C. Huang, H. T. Wu and H. Chen, "Assessment of Heavy Metal Pollution in Surface Soils of Urban Parks in Beijing, China," Chemosphere, Vol. 60, No. 4, 2005, pp. 542-551.

[11] Z. P. Yang, W. X. Lu, Y. Q. Long and X. R. Liu, "Prediction and Precaution of Heavy Metal Pollution Trend in Urban Soils," Urban Environment and Urban Ecology, Vol. 23, No. 3, 2010, pp. 1-4.

[12] P. Guo, Z. L. Xie, J. Li, C. L. Kang and J. H. Liu, "Relationships between Fractionations of $\mathrm{Pb}, \mathrm{Cd}, \mathrm{Cu}, \mathrm{Zn}$ and $\mathrm{Ni}$ and Soil Properties in Urban Soils of Changchun City," Chinese Geographical Science, Vol. 15, No. 2, 2005, pp. 179-185.

[13] T. Zhou, C. Z. Xi, T. G. Dai and D. Y. Huang, "Comprehensive Assessment of Urban Geological Environment in Changsha City," Guangdong Trace Elements Science (In Chinese), Vol. 15, No. 6, 2008, pp. 32-38.

[14] Z. P. Li, Y. C. Chen, X. C. Yang and S. Q. Wei, "Assessment of Potential Ecological Hazard of Heavy Metals in Urban Soils in Chongqing City," Journal of Southwest Agricutral University Natural Science (in Chinese), Vol. 28, No. 2, 2006, pp. 227-230.

[15] T. Chen, X. M. Liu, M. Z. Zhu, K. L. Zhao, J. J. Wu and J. M. Xu and P. Huang, "Identification of Trace Element Sources and Associated Risk Assessment in Vegetable Soils of the Urban-Rural Transitional Area of Hangzhou, China," Environmental Pollution, Vol. 151, No. 1, 2008, pp. 67-78.

[16] K. L. Spencer, "Spatial Variability of Metals in the Inter-Tidal Sediments of the Medway Estuary, Kent, UK," Marine Pollution Bulletin, Vol. 44, No. 9, 2002, pp. 933944.

[17] M. J. Attrill and R. M. Thomes, "Heavy Metal Concentrations in Sediment from the Thames Estuary, UK," Ma- rine Pollution Bulletin Vol. 30, No. 11, 1995, pp. 742744.

[18] J. Gonzalez-Perez, J. de Andres, L. Clemente, J. Martin and F. Gonzalez-Vila, "Organic Carbon and Environmental Quality of Riverine and Off-Shore Sediments from the Gulf of Cadiz, Spain," Environmental Chemistry Letters, Vol. 6, No. 1, 2008, pp. 41-46.

[19] S. Fdez-Ortiz de Vallejuelo, G. Arana, A. de Diego and J. M. Madariaga, "Risk Assessment of Trace Elements in Sediments: The Case of the Estuary of the Nerbioilbaizabal River (Basque Country)," Journal of Hazardous Materials, Vol. 181, No. 1-3, 2010, pp. 565-573.

[20] E. Prohic and G. Kniewald, "Heavy Metal Distribution in Recent Sediments of the Krka River Estuary-An Example of Sequential Extraction Analysis," Marine Chemistry, Vol. 22, 1987, pp. 279-297.

[21] M. Zhang, Z. He, P. Stoffella, D. Calvert, X. Yang and P. Sime, "Concentrations and Solubility of Heavy Metals in Muck Sediments from the St. Lucie Estuary, USA," Environmental Geology, Vol. 44, No. 1, 2003, pp. 1-7.

[22] M. A. Rubio and F. Nombela, "Geochemistry of Major and Trace Elements in Sediments of the Ria de Vigo (NW Spain): An Assessment of Metal Pollution," Marine Pollution Bulletin, Vol. 40, No. 11, 2000, pp. 968-980.

[23] D. Harland and A. T. Wither, "The Distribution of Mercury and Other Trace Metals in the Sediments of the Mersey Estuary over 25 Years 1974-1998," Science of the Total Environment, Vol. 253, No. 1-3, 2000, pp. 45-62.

[24] J. Feng, H. Kirk, B. J. Cochran, D. J. Lwiza and B. Hirschberg, "Distribution of Heavy Metal and PCB Contaminants in the Sediments of an Urban Estuary: The Hudson River," Marine Pollution Reseach, Vol. 45, No. 1, 1998, pp. 69-88.

[25] L. Carman, Z. Xiang-Dong, W. Gan and L. Onyx, "Trace Metal Distribution in Sediments of the Pearl River Estuary and the Surrounding Coastal Area, South China," Environmental Pollution, Vol. 147, No. 2, 2007, pp. 311 323.

[26] S. Duquesne, L. C. Newton, L. Giusti, S. B. Marriott, H. J. Stark and D. J. Bird, "Evidence for Declining Levels of Heavy-Metals in the Severn Estuary and Bristol Channel UK and Their Spatial Distribution in Sediments," Environmental Pollution, Vol. 143, No. 2, 2006, pp. 187-196.

[27] S. Franc. A. C. Vinagre, I. C. ador and H. N. Cabrl, "Heavy Metal Concentrations in Sediment, Benthic Invertebrates and Fish in Three Salt Marsh Areas Subjected to Different Pollution Loads in the Tagus Estuary (Portugal)," Marine Pollution Bulletin, Vol. 50, No. 9, 2005, pp. 998-1003.

[28] R. Prego and A. Cobelo-Garcia, "Twentieth Century Overview of Heavy Metals in the Galician Rias (NW Iberian Peninsula)," Environmental Pollution, Vol. 121, No. 3, 2003, pp. 425-452.

[29] A. J. Marmolejo-Rodriguez, R. Prego, A. Meyer-Willerer, E. Shumilin and A. Cobelo-Garcia, "Total and Labile Metals in Surface Sediments of the Tropical River-Estuary System of Marabasco (Pacific Coast of Mexico): Influence of an Iron Mine," Marine Pollution Bulletin, Vol. 55, No. 
10-12, 2007, pp. 459-468.

[30] N. Fernandez, J. Bellas, J. Lorenzo and R. Beiras, "Complementary Approaches to Assess the Environmental Quality of Estuarine Sediments," Water, Air, and Soil Pollution, Vol. 189, No. 1-4, 2008, pp. 163-177.

[31] M. Jayaprakash, M. P. Jonathan, S. Srinivasalu, S. Muthuraj, V. Ram-Mohan and N. Rajeshwara-Rao, "AcidLeachable Trace Metals in Sediments from an Industrialized Region (Ennore Creek) of Chennai City, SE Coast of India: An Approach towards Regular Monitoring, Estuarine Coast," Estuarine, Coastal and Shelf Science, Vol. 76, No. 3, 2008, pp. 692-703. doi:10.1016/j.ecss.2007.07.035

[32] G. Abrahim and R. Parker, "Assessment of Heavy Metal Enrichment Factors and the Degree of Contamination in Marine Sediments from Tamaki Estuary, Auckland, New Zealand," Environmental Monitoring and Assessment, Vol. 136, No. 1-3, 2008, pp. 227-238. doi:10.1007/s10661-007-9678-2

[33] F. Liu, W. Yan, W. Z. Wang, S. C. Gu and Z. Chen, "Pollution of Heavy Metals in the Pearl River Estuary and Its Assessment of Potential Ecological Risk," Marine Environmental Science, Vol. 21, No. 3, 2002, pp. 34-38.

[34] X. Huang, X. Li, W. Yue, L. Huang and Y. Li, "Accumulation of Heavy Metals in the Sediments of Shenzhen Bay, South China," Environmental Science (in Chinese with English Abstract), Vol. 24, No. 4, 2003, pp. 144-149.

[35] X. D. Xu, Z. H. Lin and S. Q. Li, "The Studied of the Heavy Metal Pollution of Jiaozhou Bay," Marine Sciences (in Chinese with English Abstract), Vol. 29, No. 1, 2005, pp. 48-53.

[36] R. L. Yu, X. Yuan, Y. H. Zhao, G. R. Hu and X. L. Tu, "Heavy Metal Pollution in Intertidal Sediments from Quanzhou Bay, China," Journal of Environmental Sciences, Vol. 20, No. 6, 2008, pp. 664-669. doi:10.1016/S1001-0742(08)62110-5

[37] L. P. Zhang, X. Ye, H. Feng, Y. H. Jing, O. Y. Tong, X. T. Yu, R. Y. Liang, C. T. Gao and W. Q. Chen, "Heavy Metal Contamination in Western Xiamen Bay Sediments and Its Vicinity, China," Marine Pollution Bulletin, Vol. 54, No. 7, 2007, pp. 974-982. doi:10.1016/j.marpolbul.2007.02.010

[38] USEPA-Region II, USACE-New York District, USDOEBNL, "Fast Track Dredged Material Decontamination Demonstration for the Port of New York and New Jersey," 1999.

[39] A. Filibeli and R. Yilmaz, "Dredged Material of Izmir Harbor: Its Behavior and Pollution Potential," Water Science and Technology, Vol. 32, No. 2, 1995, pp. 105-113. doi:10.1016/0273-1223(95)00575-8

[40] M. H. Bothner, T. B. Buchholtz and F. T. Manheim, "Metal Concentrations in Surface Sediments of Boston HarborChanges with Time," Marine Environmental Research, Vol. 45, No. 2, 1998, pp. 127-155. doi:10.1016/S0141-1136(97)00027-5

[41] CSBTS (China State Bureau of Quality and Technical Supervision), "Marine Sediment Quality," Standards Press of China, Beijing, 2002.
[42] L. Zhu, J. Xu, F. Wang and B. Lee, "An Assessment of Selected Heavy Metal Contamination in the Surface Sediments from the South China Sea before 1998," Journal of Geochemical Exploration, Vol. 108, No. 1, 2011, pp. 1-14. doi:10.1016/i.gexplo.2010.08.002

[43] G. D. Du, "White Paper on China's Drug Supervision," 2008.

http://news.xinhuanet.com/english/2008-07/18/content_8 567067 4.htm

[44] R. L. Nahin, P. M. Barnes, B. J. Stussman and B. Bloom, "Costs of Complementary and Alternative Medicine (CAM) and Frequency of Visits to CAM Practitioners: United States, 2007," National Health Statistic Reports, Vol. 30 , No. 18, 2009, pp. 1-14.

[45] D. M. Eisenberg, R. B. Davis, S. L. Ettner, S. Appel, S. Wilkey and M. van Rompay, "Trends in Alternative Medicine Use in the United States, 1990-1997-Results of a Follow-Up National Survey," The Journal of the American Medical Association, Vol. 280, No. 18, 1998, pp. 1569-1575. doi:10.1001/jama.280.18.1569

[46] S. J. Eric, C. A. C. Shugeng, A. B. Littlefield, A. J. Craycroft, R. Scholten, T. Kaptchuk, Y. L. Fu, W. Q. Wang, Y. Liu, H. B. Chen, Z. Z. Zhao, J. Clardy, A. D. Woolf and D. M. Eisenberg, "Heavy Metal and Pesticide Content in Commonly Prescribed Individual Raw Chinese Herbal Medicines," Science of the Total Environment, Vol. 409, No. 20, 2011, pp. 4297-4305.

[47] J. Liu, Y. F. Lu, Q. Wu, R. Goyer and M. P. Waalkes, "Mineral Arsenicals in Traditional Medicines: Orpiment, Realgar, and Arsenolite," Pharmacology, Vol. 326, No. 2, 2008, pp. 363-368. doi:10.1124/jpet.108.139543

[48] J. Liu, J. Z. Shi, L. M. Yu, R. A. Goyer and M. P. Waalkes, "Mercury in Traditional Medicines: Is Cinnabar Toxicologically Similar to Common Mercurials?" Experimental Biology and Medicine, Vol. 233, No. 7, 2008, pp. 810-817. doi:10.3181/0712-MR-336

[49] R. B. Saper, R. S. Phillips, A. Sehgal, N. Khouri, R. B. Davis and J. Paquin, "Lead, Mercury, and Arsenic in USand Indian-Manufactured Ayurvedic Medicines Sold via the Internet," The Journal of the American Medical Association, Vol. 300, No. 8, 2008, pp. 915-923.

2008. doi:10.1001/jama.300.8.915

[50] Y. F. Lu, Q. Wu, W. Miao, J. S. Shi and J. Liu, "Evaluation of Hepatotoxicity Potential of Cinnabar-Containing. An-Gong-Niu-Huang Wan, a Patent Traditional Chinese Medicine," Regulatory Toxicology and Pharmacology, Vol. 60, No. 2, 2011, pp. 206-211. doi:10.1016/j.yrtph.2011.03.007

[51] A. Hamzah, C. W. Beh, S. B. Sarmani and J. Y. Liow, "Abugassa Studies on Elemental Analysis of Chinese Traditional Herbs by Neutron Activation Technique and Their Mutagenic Effect," Journal of Radioanalytical and Nuclear Chemistry, Vol. 259, No. 3, 2004, pp. 499-503.

[52] L. I. Qin, C. Chu, Y. Q. Wang, H. B. Chen, L. I. Ping and Z. Z. Zhao, "Authentication of the 31 Species of Toxic and Potent Chinese Materia Medica by Microscopic Technique Assisted by ICP-MS Analysis, Part 4: Four Kinds of Toxic and Potent Mineral Arsenical CMMs," Microscopy Research and Technique Journal, Vol. 74, 
No. 1, 2011, pp. 1-8

[53] A. M. Evens, M. S. Tallman and R. B. Gartenhaus, "The Potential of Arsenic Trioxide in the Treatment of Malignant Disease: Past, Present, and Future," Leukemia Research, Vol. 28, No. 9, 2004, pp. 891-900. doi:10.1016/j.leukres.2004.01.011

[54] Chinese Pharmacopoeia Commission, "Pharmacopoeia of the People's Republic of China," People's Medical Publishing House, Beijing, 2005.

[55] M. Lin, Z. Y. Wang and D. S. Zhang, "Preparation of $\mathrm{As}_{2} \mathrm{~S}_{3}$ Nanoparticles and Their Therapeutic Effect on liver Cancer SMMC-7721 Cells," Journal of Southeast University (Natural Science Edition), Vol. 2, No. 36, 2006, pp. 298-302.

[56] M. Lin and D. S. Zhang, "Effect of Orpiment Nanoparticles on Telomerase Activity in K562 Cell Line," Journal of the Medical Sciences, Vol. 11, No. 6, 2007, pp. 5-7.

[57] K. Cooper, B. Noller, D. Connell, J. Yu, R. Sadler, H. Olszowy, G. Golding, U. Tinggi, M. R. Moore and S. Myers, "Public Health Risks from Heavy Metals and Metalloids Present in Traditional Chinese Medicines," Journal of Toxicology and Environmental Health A, Vol. 70, No. 19, 2007, pp. 1694-1699. doi:10.1080/15287390701434885

[58] P. Westervelt, R. A. Brown, D. R. Adkins, H. Khoury, P. Curtin, D. Hurd, S. M. Luger, M. K. Ma, T. J. Ley and J. F. Dipersio, "Sudden Death among Patients with Acute Promyelocytic Leukemia Treated with Arsenic Trioxide," Blood, Vol. 98, No. 2, 2001, pp. 266-271. doi:10.1182/blood.V98.2.266

[59] A. Liang, J. Wang, B. Xue, C. Li, T. Liu, Y. Zhao, C. Cao and Y. Yi, "Study on Hepatoxicity and Nephrotoxicity of Cinnabar in Rats," Zhongguo Zhong Yao Za Zhi, Vol. 34, No. 3, 2009, pp. 312-328.

[60] J. Liu, J. Z. Shi, L. M. Yu, A. R. Goyer and M. P. Waalkes, "Mercury in Traditional Medicines: Is Cinnabar Toxicologically Similar to Common Mercurials?" Journal of Experimental Biology and Medicine, Vol. 233, No. 7, 2008, pp. 810-817.

[61] C. D. Klaassen, "Heavy Metals and Heavy-Metal Antagonists," In: J. G. Hardman, L. E. Limbird and A. G. Gilman, Eds., The Pharmacological Basis of Therapeutics, McGraw-Hill, New York, 2001, pp. 1851-1876.

[62] Agency for Toxic Substances and Disease Registry, "Toxicological Profile for Mercury (Update)," Agency for Toxic Substances and Disease Registry, Atlanta, 1999.

[63] J. F. Risher, H. E. Murray and G. R. Prince, "Organic Mercury Compounds: Human Exposure and Its Relevance to Public Health," Toxicology and Industrial Health, Vol. 18, No. 3, 2002, pp. 109-160. doi:10.1191/0748233702th1380a

[64] G. Z. Lin, F. Wu, C. H. Yan, et al., "Childhood Lead Poisoning Associated with Traditional Chinese Medicine: A Case Report and the Subsequent Lead Source Inquiry," Clinica Chimica Acta, Vol. 413, No. 13-14, 2012, pp. 11561159. doi:10.1016/j.cca.2012.03.010

[65] G. C. Fang, Y. L. Huang and J. H. Huang, "Study of Atmospheric Metallic Elements Pollution in Asia during
2000-2007," Journal of Hazardous Materials, Vol. 180, No. 1-3, 2010, pp. 115-121.

doi:10.1016/j.jhazmat.2010.03.120

[66] J. D. Marth, "A Unified Vision of the Building Blocks of Life," Nature Cell Biology, Vol. 10, No. 9, 2008, pp. 10151016. doi:10.1038/ncb0908-1015

[67] B. Rowley and M. Monestier, "Mechanisms of Heavy Metal-Induced Autoimmunity," Molecular Immunology, Vol. 42, No. 7, 2005, pp. 833-838. doi:10.1016/i.molimm.2004.07.050

[68] K. M. Pollard, P. Hultman and D. H. Kono, "Toxicology of Autoimmune Diseases," Chemical Research in Toxicology, Vol. 23, No. 3, 2010, pp. 455-466.

[69] S. Bernard, A. Enayati, H. Roger, T. Binstock and L. Redwood, "The Role of Mercury in the Pathogenesis of Autism," Molecular Psychiatry, Vol. 7, No. 2, 2002, pp. S42-S43. doi:10.1038/sj.mp.4001177

[70] J. M. Gorell, C. C. Johnson, B. A. Rybicki, E. L. Peterson, G. X. Kortsha, G. G. Brown and R. J. Richardson, "Occupational Exposures to Metals as Risk Factors for Parkinson's Disease," Neurology, Vol. 48, No. 3, 1997, pp. 650-658. doi:10.1212/WNL.48.3.650

[71] J. Shu, J. A. Dearing, A. P. Morse, L. Yu and N. Yuan, "Determining the Sources of Atmospheric Particles in Shanghai, China, from Magnetic and Geochemical Properties," Atmospheric Environment, Vol. 35, No. 15, 2001, pp. 2615-2625. doi:10.1016/S1352-2310(00)00454-4

[72] C.-F. Huang, S.-H. Liu and S. Y. Lin-Shiaub, "Neurotoxicological Effects of Cinnabar (a Chinese Mineral Medicine, HgS)," Toxicology and Applied Pharmacology, Vol. 224, No. 2, 2007, pp. 192-201. doi:10.1016/i.taap.2007.07.003

[73] R. J. Huang, Z. X. Zhuang, Y. Tai, X. R. Wang and F. S. C. Lee, "Direct Analysis of Mercury in Traditional Chinese Medicines Using Thermolysis Coupled with OnLine Atomic Absorption Spectrometry," Talanta, Vol. 68, No. 3, 2006, pp. 728-734. doi:10.1016/j.talanta.2005.05.014

[74] B. J. Alloway, "The General Monograph Herbal Drugs (1433)," Pharmeuropa, Vol. 20, No. 2, 2008, pp. 302303.

[75] Commission Regulation (EC) No. 629/2008 Amending Regulation (EC) No. 1881/2006 of 19 December 2006, "Setting Maximum Levels for Certain Contaminants in Foodstuffs," Official Journal of the European Union, Vol. 173, No. 51, 2008, pp. 6-9.

[76] T. I. Lidsky and J. S. Schneider, "Neurotoxicity in Children: Basic Mechanisms and Clinical Correlates," Brain, Vol. 126, No. 1, 2003, pp. 5-19. doi:10.1093/brain/awg014

[77] Agency for Toxic Substances and Disease Registry (ATSDR), "Toxicological Profile for Lead [Draft]," Public Health Service, US Department of Health and Human Services, Washington DC, 2005. www.atsdr.cdc.gov/toxprofiles

[78] US Centers for Disease Control and Prevention (CDC), "Third National Report on Human Exposure to Environmental Chemicals," Atlanta, 2005. 
www.cdc.gov/exposurereport/3rd/default.htm

[79] A. Menke, P. Muntner, V. Batuman, E. K. Silbergeld and E. Guallar, "Blood Lead below $0.48 \mathrm{Micromol} / 1$ (10 mi$\mathrm{crog} / \mathrm{dl})$ and Mortality among US Adults," Circulation, Vol. 114, No. 13, 2006, pp. 1388-1394. doi:10.1161/CIRCULATIONAHA.106.628321

[80] D. C. Bellinger, "Very Low Lead Exposures and Children's Neurodevelopment," Current Opinion in Pediatrics, Vol. 20, No. 2, 2008, pp. 172-177. doi:10.1097/MOP.0b013e3282f4f97b

[81] C. D. Carrington and P. M. Bolger, "An Assessment of the Hazards of Lead in Food," Regulatory Toxicology and Pharmacology, Vol. 16, No. 3, 1992, pp. 265-272. doi:10.1016/0273-2300(92)90006-U

[82] A. Gomaa, H. Hu, D. Bellinger, et al., "Maternal Bone Lead as an Independent Risk Factor for Fetal Neurotoxicity: A Prospective Study," Pediatrics, Vol. 110, Part 1, 2002, pp. 110-118. doi:10.1542/peds.110.1.110

[83] S. DeMichele, "Nutrition of Lead," Comparative Biochemistry and Physiology B-Biochemistry \& Molecular Biology, Vol. 78, No. 3, 1984, pp. 401-408.

[84] M. J. Heard and A. C. Chamberlain, "Effect of Minerals and Food on Uptake of Lead from the Gastrointestinal Tract in Humans," Human \& Experimental Toxicology, Vol. 1, No. 4, 1982, pp. 411-415. doi: $10.1177 / 096032718200100407$

[85] K. M. Six and R. A. Goyer, "Experimental Enhancement of Lead Toxicity by Low Dietary Calcium," Journal of Laboratory and Clinical Medicine, Vol. 76, No. 6, 1970, pp. 933-942.

[86] Y. Cheng, W. C. Willett, J. Schwartz, D. Sparrow, S. Weiss and $\mathrm{H}$. Hu, "Relation of Nutrition to Bone Lead and Blood Lead Levels in Middle-Aged to Elderlymen. The Normative Aging Study," American Journal of Epidemiology, Vol. 147, No. 12, 1998, pp. 1162-1174. doi:10.1093/oxfordjournals.aje.a009415

[87] T. W. Clarkson, "The Three Modern Faces of Mercury," Environmental Health Perspectives, Vol. 110, No. S1, 2002, pp. 11-23. doi:10.1289/ehp.02110s111

[88] S. A. Counter and L. H. Buchanan, "Mercury Exposure in Children: A Review," Toxicology and Applied Pharmacology, Vol. 198, No. 2, 2004, pp. 209-230. doi:10.1016/j.taap.2003.11.032

[89] I. Kosalec, J. Cvek and S. Tomic, "Contaminants of Medicinal Herbs and Herbal Products," Archives of Industrial Hygiene and Toxicology, Vol. 60, No. 4, 2009, pp. 485-501. doi:10.2478/10004-1254-60-2009-2005

[90] US Centers for Disease Control and Prevention (CDC), "Third National Report on Human Exposure to Environmental Chemicals," 2005. www.cdc.gov/exposurereport/3rd/default.htm

[91] Association of Toxic Substances and Disease Registry (ATSDR), "Toxicological Profile for Mercury (Update)," Department of Health and Human Services, Atlanta, 2006. http://www.atsdr.cdc.gov/toxprofiles/tp46.html

[92] J. H. Roberts, "Metal Toxicity in Children, Training Manual on Pediatric Environmental Health: Putting It into Practice," 2005. http://www.cehn.org/cehn/trainingmanual/manual-front.ht $\mathrm{ml}$

[93] W. H. Miller, H. M. Schipper, J. S. Lee, J. Singer and S. Waxman, "Mechanisms of Action of Arsenic Trioxide," Cancer Research, Vol. 62, No. 14, 2002, pp. 3893-3903.

[94] World Health Organization (WHO), "WHO Guidelines for Assessing Quality of Herbal Medicines with Reference to Contaminants and Residue," WHO, Geneva, 2007.

[95] B. Liu, X. Lv, D. Wang, Y. Xu, L. Zhang and Y. Li, “Adsorption Behavior of As(III) onto Chitosan Resin with As(III) as Template Ions," Journal of Applied Polymer Science, Vol. 125, No. 1, 2012, pp. 246-253. doi:10.1002/app.35528

[96] M. Vahter, "Health Effects of Early Life Exposure to Arsenic," Basic \& Clinical Pharmacology \& Toxicology, 102, No. 2, 2008, pp. 204-211. doi:10.1111/j.1742-7843.2007.00168.x

[97] E. J. Tokar, W. Qu and M. P. Waalkes, "Arsenic, Stem Cells, and the Developmental Basis of Adult Cancer," Toxicological Sciences, Vol. 120, No. S1, 2011, pp. S192-S203. doi: $10.1093 /$ toxsci/kfq342

[98] M. P. Waalkes and J. Liu, "Early-Life Arsenic Exposure: Methylation Capacity and Beyond," Environmental Health Perspectives, Vol. 116, No. 3, 2008, pp. A104-A104. doi:10.1289/ehp.11276

[99] K. L. Huyck, M. L. Kile, G. Mahiuddin, Q. Quamruzzaman, M. Rahman, et al., "Maternal Arsenic Exposure Associated with Low Birth Weight in Bangladesh," Journal of Occupational and Environmental Medicine, Vol. 49, No. 10, 2007, pp. 1097-1104. doi:10.1097/JOM.0b013e3181566ba0

[100] R. Quansah and J. J. K. Jaakkola, "Paternal and Maternal Exposure to Welding Fumes and Metal Dusts or Fumes and Adverse Pregnancy Outcomes," International Archives of Occupational and Environmental Health, Vol. 82, No. 4, 2009, pp. 529-537. doi:10.1007/s00420-008-0349-6

[101] J. Thompson and J. Bannigan, "Cadmium: Toxic Effects on the Reproductive System and the Embryo," Reproductive Toxicology, Vol. 25, No. 3, 2008, pp. 304-315. doi:10.1016/j.reprotox.2008.02.001

[102] J. Liaw, G. Marshall, Y. Yuan, C. Ferreccio, C. Steinmaus, et al., "Increased Childhood Liver Cancer Mortality and Arsenic in Drinking Water in Northern Chile," Cancer Epidemiology Biomarkers \& Prevention, Vol. 17, No. 8, 2008, pp. 1982-1987. doi:10.1158/1055-9965.EPI-07-2816

[103] J. Liu and M. P. Waalkes, "Liver Is a Target of Arsenic Carcinogenesis," Toxicological Sciences, Vol. 105, No. 1, 2008, pp. 24-32. doi:10.1093/toxsci/kfn120

[104] A. Anzblau and R. Lilis, "Acute Arsenic Intoxication from Environmental Arsenic Exposure," Archives of Environmental Health: An International Journal, Vol. 44, No. 6, 1989, pp. 385-390. doi:10.1080/00039896.1989.9935912

[105] W. H. Mielke and S. Zahran, "The Urban Rise and Fall of Air Lead $(\mathrm{Pb})$ and the Latent Surge and Retreat of Societal Violence," Environment International, Vol. 43, 2012, 
pp. 48-55. doi:10.1016/j.envint.2012.03.005

[106] J. A. Menezes-Filho, G. F. de S. Viana and C. R. Paes, "Determinants of Lead Exposure in Children on the Outskirts of Salvador, Brazil," Environmental Monitoring and Assessment, Vol. 184, No. 4, 2012, pp. 2593-2603. doi:10.1007/s10661-011-2137-0

[107] E. Nicholas, W. J. C. Pingitore Jr., A. M. A. Beata and M. J. J. Reynoso, "Urban Airborne Lead: X-Ray Absorption Spectroscopy Establishes Soil as Dominant Source," The Smithsonian/NASA Astrophysics Data System, Vol. 4, No. 4, 2009, p. e5019.

[108] L. Luo, B. Chu, Y. Li, T. Xu, X. Wang, J. Yuan, J. Sun, Y. Liu, Y. Bo, X. Zhan, S. Wang and L. Tang, "Determination of $\mathrm{Pb}, \mathrm{As}, \mathrm{Cd}$ and Trace Elements in Polluted Soils near a Lead-Zinc Mine Using Polarized X-Ray Fluorescence Spectrometry and the Characteristics of the Elemental Distribution in the Area," X-Ray Spectrometry, Vol. 41, No. 3, 2012, pp. 133-143. doi:10.1002/xrs.2364

[109] G. Z. Lin, F. Wu, C. H. Yan, K. Li and X. Y. Liu, "Childhood Lead Poisoning Associated with Traditional Chinese Medicine: A Case Report and the Subsequent Lead Source Inquiry," Clinica Chimica Acta, Vol. 413, No. 1314, 2012, pp. 1156-1159. doi:10.1016/j.cca.2012.03.010

[110] H. Bae, "Reducing Environmental Risks by Information Disclosure: Evidence in Residential Lead Paint Disclosure Rule," Journal of Policy Analysis and Management, Vol. 31, No. 2, 2012, pp. 404-431. doi: $10.1002 /$ pam. 21600

[111] F. Barbosa, C. D. Palmer, F. J. Krug, P. J. Parsons and J. Anal, "Determination of Total Mercury in Whole Blood by Flow Injection Cold Vapor Atomic Absorption Spectrometry with Room Temperature Digestion Using Tetramethylammonium Hydroxide," Atomic Spectroscopy, Vol. 19, No. 8, 2004, pp. 100-1005. doi:10.1039/b400315b

[112] S. Q. Tao, S. F. Gong, L. Xu and J. C. Fanguy, "Mercury Atomic Absorption by Mercury Atoms in Water Observed with a Liquid Core Waveguide as a Long Path Absorption Cell," Analyst, Vol. 129, No. 4, 2004, pp. 342346. doi:10.1039/b400426d

[113] L. P. Yu and X. P. Yan, "Flow Injection On-Line Sorption Preconcentration Coupled with Cold Vapor Atomic Fluorescence Spectrometry and On-Line Oxidative Elution for the Determination of Trace Mercury in Water Samples," Atomic Spectroscopy, Vol. 25, No. 3, 2004, pp. 145-153.

[114] G. Centineo, E. B. Gonzalez and A. Sanz-Medel, "MultiElemental Speciation Analysis of Organometallic Compounds of Mercury, Lead and Tin in Natural Water Samples by Headspace-Solid Phase Microextraction Followed by Gas Chromatography-Mass Spectrometry," Journal of Chromatography A, Vol. 1034, No. 1-2, 2004, pp. 191197. doi:10.1016/j.chroma.2004.01.051

[115] H. P. Chen, D. C. Paschal, D. T. Miller and J. D. C. Morrow, "Determination of Total and Inorganic Mercury in Whole Blood by On-Line Digestion with Flow Injection," Atomic Spectroscopy, Vol. 19, 1998, pp. 176-179.

[116] P. J. Parsons, C. D. Palmer, K. L. Caldwell and R. L. Jones, "Determination of Total Mercury in Urine by Induc- tively Coupled Plasma Mass Spectrometry (ICP-MS)," Royal Society of Chemistry, London, 2005.

[117] S. H. Rogers, N. Jeffery, S. Kieszak, P. Fritz, H. Spliethoff, D. Christopher, P. J. P. Parsons, E. Daniel, K. K. Caldwell, G. Eadon and C. Rubin, "Mercury Exposure in Young Children Living in New York City," Journal of Urban Health: Bulletin of the New York Academy of Medicine, Vol. 85, No. 1, 2007, pp. 39-51.

[118] W. B. Zhang, Z. F. Su, X. F. Chu and X. A. Yang, "Evaluation of a New Electrolytic Cold Vapor Generation System for Mercury Determination by AFS," Talanta, Vol. 80, No. 5, 2010, pp. 2106-2112. doi:10.1016/j.talanta.2009.11.016

[119] X. R. Wang, Z. X. Zhuang, D. H. Sun, J. X. Hong, X. H. Wu, F. S. C. Lee, F. S. C. Lee, M. S. Yang and H. W. Leung, "Trace Metals in Traditional Chinese Medicine: A Preliminary Study Using ICP-MS for Metal Determination and as Speciation," Atomic Spectroscopy, Vol. 20, No. 3, 1999, p. 86.

[120] S. Scholupov, S. Pogarev, V. Ryzhov, N. Mashyanov and A. Stroganov, "Zeeman Atomic Absorption Spectrometer RA-915+ for Direct Determination of Mercury in Air and Complex Matrix Samples," Fuel Processing Technology, Vol. 85, No. 6-7, 2004, pp. 473-485. doi:10.1016/j.fuproc.2003.11.003

[121] R. J. Huang, Z. X. Zhuang, R. F. Huang, X. R. Wang and F. S. C. Lee, "Direct Analysis of Mercury in Traditional Chinese Medicines Using Thermolysis Coupled with OnLine Atomic Absorption Spectrometry," Talanta, Vol. 68, No. 3, 2006, pp. 728-734. doi:10.1016/j.talanta.2005.05.014

[122] J. G. Tian, Y. Lu, J. G. Zhou, T. B. Gao, Q. T. Zheng and D. C. Chen, "The Powder X-Ray Diffraction Analysis of Mineral Drug Realgar with Its Associated Minerals," Chinese Journal of Clinical Pharmacy, No. 2, 1998, pp. 8689.

[123] H. Jiang, Y. H. Zhang, J. H. Ding, S. T. Shi, P. Xue, S. Gao, H. Z. Gong and G. F. Sun, "Determination of As(III) Content in Realgar by HPLCHG-AFS," Chemical Research, Vol. 19, 2008, pp. 67-69.

[124] G. Li, Y. K. Cheng, C. G. Huang, K. R. Li and Q. A. Wu, "Analysis on the Mineral Chinese Medicine Realgar," Nanjing Shidan Xue Bao (Natural Science Edition), Vol. 31, 2008, pp. 63-67.

[125] L. W. Zhang, Y. H. Xie, S. L. Dong, Y. Y. Zhang and G. H. Su, "Researches on Arsenic and Its Appearance Analysis in Chinese Medicines (Review)," Clinical Pharmacy, Vol. 11, 2008, pp. 578-581.

[126] S. Latva, M. Hurtta, S. Peraniemi and M. Ahlgren, "Separation of Arsenic Species in Aqueous Solutions and Optimization of Determination by Graphite Furnace Atomic Absorption Spectrometry," Analytica Chimica Acta, Vol. 418, No. 1, 2000, pp. 11-17. doi:10.1016/S0003-2670(00)00947-8

[127] J. Dedina and D. L. Tsalev, "Hydride Generation Atomic Absorption Spectrometry," Wiley, Chichester, 1995.

[128] P. Carrero, A. Malave, J. L. Burguera, M. Burguera and C. Rondon, "Determination of Various Arsenic Species by 
Flow Injection Hydride Generation Atomic Absorption Spectrometry: Investigation of the Effects of the Acid Concentration of Different Reaction Media on the Generation of Arsines," Analytica Chimica Acta, Vol. 438, No. 1-2, 2001, pp. 195-204. doi:10.1016/S0003-2670(01)00796-6

[129] W. E. Gan, W. B. Zhang and X. Q. Lin, "Electrochemical Hydride Generation Atomic Fluorescence Spectrometry for the Simultaneous Determination of Arsenic and Antimony in Chinese Medicine Samples," Analytica Chimica Acta, Vol. 539, No. 1-2, 2005, pp. 335-340. doi:10.1016/j.aca.2005.03.050

[130] H. M. Anawara, "Arsenic Speciation in Environmental Samples by Hydride Generation and Electrothermal Atomic Absorption Spectrometry," Talanta, Vol. 88, No. 28, 2012, pp. 30-42. doi:10.1016/j.talanta.2011.11.068

[131] G. Pearson and G. Greenway, "A Highly Efficient Sample Introduction System for Interfacing Microfluidic Chips with ICP-MS," Journal of Analytical Atomic Spectrometry, Vol. 22, No. 6, 2007, pp. 657-662. doi:10.1039/b702624b

[132] X. D. Tian, Z. X. Zhuang, B. Chen and X. R. Wang, "Movable Reduction Bed Hydride Generation System as an Interface for Capillary Zone Electrophoresis and Inductively Coupled Plasma Atomic Emission Spectrometry for Arsenic Speciation Analysis," Analyst, Vol. 123, No. 5, 1998, pp. 899-903. doi:10.1039/a707452b

[133] Y. Liu and V. Lopez-Avila, "On-Line Microwave-Induced Helium Plasma Atomic Emission Detection for Capillary Zone Electrophoresis," Journal of High Resolution Chromatography, Vol. 16, No. 12, 1993, pp. 717-720. doi:10.1002/jhrc. 1240161209

[134] H. Matusiewicz and M. Ślachciński, "Method Development for Simultaneous Multielement Determination of Hydride Forming Elements (As, Bi, Ge, Sb, Se, Sn) and $\mathrm{Hg}$ by Microwave Induced Plasma-Optical Emission Spectrometry Using Integrated Continuous-Microflow Ultrasonic Nebulizer-Hydride Generator Sample Intro- duction System," Microchemical Journal, Vol. 95, No. 2, 2010, pp. 213-221. doi:10.1016/j.microc.2009.12.004

[135] H. Matusiewicz and B. Golik, "Determination of Major and Trace Elements in Biological Materials by Microwave Induced Plasma Optical Emission Spectrometry (MIP-OES) Following Tetramethylammonium Hydroxide (TMAH) Solubilization," Microchemical Journal, Vol. 76, No. 1-2, 2004, pp. 23-29. doi:10.1016/j.microc.2003.10.007

[136] K. Jankowski and A. Jackowska, "Spectroscopic Diagnostics for Evaluation of the Analytical Potential of Argon + Heliummicrowave-Induced Plasma with Solution Nebulization," Journal of Analytical Atomic Spectrometry, Vol. 22, No. 9, 2007, pp. 1076-1082. doi: $10.1039 / \mathrm{b} 705288 \mathrm{j}$

[137] H. Matusiewicz and M. Ślachciński, "Development of a New Hybrid Technique for Inorganic Arsenic Speciation Analysis by Microchip Capillary Electrophoresis Coupled with Hydride Generation Microwave Induced Plasma Spectrometry," Microchemical Journal, Vol. 102, 2012, pp. 61-67.

[138] Q. J. Song, G. M. Greenway and T. McCreedy, "Interfacing a Microfluidic Electrophoresis Chip with Inductively Coupled Plasma Mass Spectrometry for Rapid Elemental Speciation," Journal of Analytical Atomic Spectrometry, Vol. 19, No. 7, 2004, pp. 883-887. doi:10.1039/b401657b

[139] H. Matusiewicz and M. Ślachciński, "Interfacing a Microchip-Based Capillary Electrophoresis System with a Microwave Induced Plasma Spectrometry for Copper Speciation," Central European Journal of Chemistry, Vol. 9 , No. 5, 2011, pp. 896-903. doi:10.2478/s11532-011-0079-6

[140] H. Matusiewicz and M. Ślachciński, "Interfacing a Microchip-Based Capillary Electrophoresis System with a Microwave Induced Plasma Spectrometry for Copper Speciation," Central European Journal of Chemistry, Vol. 9, No. 5, 2011, pp. 896-903. 